\title{
Relationship Between Mode of Financing and Financial Performance of Deposit Taking Savings and Credit Cooperative Societies in the Lake Region Counties of Kenya
}

\author{
David Kipkorir Cheruiyot ${ }^{1} \quad$ Dr. Michael Njoroge Njogo ${ }^{2}$ \\ 1.MSC (Finance and Investment) graduate: School of Business, KCA University \\ 2.Lecturer, School of Business, KCA University
}

\begin{abstract}
Mode of financing is an important factor for consideration when it comes to firm financial performance. Several studies show that highly leveraged organizations usually do well in terms of financial growth by increasing the value of a firm, contrary to the MM theorem that argues that capital structure is irrelevant factor to consider since it does not affect the value of an organization. This study focused on establishing the relationship between share capital, retained earnings, members' deposits, debt financing and financial performance of SACCOs in the Lake Region Counties of Kenya. The study was prompted by the increase in the number of SACCOs in the Lake Region Counties facing financial difficulties resulting to low returns to investors and in some instances, SACCOs being de-registered by SASRA for not meeting the SASRA regulations, thus threatening the wellbeing of the lake region's economy. The study adopted explanatory research design and the target population was all the 34-deposit taking SACCOs in the Lake Region Counties of Kenya. Secondary data was obtained from the annual reports and financial statements of the 34 DT-SACCOs were used for analysis. The annual reports and financial statements were sourced from the official website of SASRA and the respective official websites of the DT-SACCOs. The period of study was stretch from year 2015 to year 2019. The collected data was converted into panels and fed into STATA version 14 for analysis. The data was analyzed using descriptive statistics, correlation analysis and panel data regression analysis. The study revealed that share capital has an insignificant positive relationship with performance of SACCOs in the lake region while retained earnings has a significant effect on financial performance of SACCOs in the lake region. The study also showed that debt financing has a significant negative effect on financial performance of SACCOs in the lake region. The study recommends DT SACCO management to exploit internal source of financing such as retained earnings and share capital. It also recommends that DT SACCOs should avoid expensive debts but instead sought loans with favorable terms.
\end{abstract}

Keywords: Mode of financing, financial performance, Deposit taking Savings and credit cooperative societies DOI: $10.7176 / \mathrm{EJBM} / 13-23-04$

Publication date: December $31^{\text {st }} 2021$

\section{Introduction}

Business enterprises are usually funded with combination of debt and equity, commonly called capital structure. Firms normally fund part of their assets with internal sources, that is, ordinary shares, preference shares and retained earnings while on the other part through debt financing that is through loaning (either internal, external or both) hence, a financial structure comprises of short and long term debt financing (Moyer et. al., 1999). The capital make-up decision is one of the most important choices that a business enterprise takes since it has a bearing on the company's financial performance. Financial make-up is the extent to which total funds are available to finance the total assets of a firm and it comprises of both long-term resources and short-term resources (Pandey, 2015).

Capital refers to the funds an organization requires to carry out its day-to-day business operations. There are two major sources of capital in an organization, which are equity and debt. Equity refers to internal financing whereby the owner of an enterprise contributes funds to raise capital for running an enterprise. Thereafter, additional equity financing is usually done through plowing back profits to the business rather than paying out as dividends, issuing shares to the existing owners or shareholders and or making new share issues to the members of the public. Debt capital is money raised by an organization from external creditors inform of loans (Peterson, 2017).

Financial performance of a SACCO can be evaluated by use of financial ratios or through other comprehensive financial analysis methods such as common size analysis. A financial analyst uses financial ratios to determine firm's performance whereas an investor uses the same to establish the potential risk and return that can be realized upon investing in a firm's securities (Fabozzi \& Peterson, 2003). Through the use of ratios, the business owners can be able to understand whether their business have met the objective of being wealthier and how competitive their business has been as compared to business ratios of other firms in the same sector or otherwise the trend performance of the business over time (Milcah \& Muturi, 2016). This study adopted return on assets as the estimate of financial performance of SACCOs in the Counties of the Lake Region of Kenya. 
SACCOS are licensed, legal institutions that are brought about and regulated by the pertinent laws of a given Country. They are stand-alone corporation of individuals who discretionary come together to meet shared economic, social-cultural responsibility and desires through jointly owning and democratically regulating their business enterprise. SACCOS are beneficial to members since they bring member's savings together and in return use the pooled savings to advance credit to members who pay back at an affordable interest rate where the members themselves guarantee one another (Dana, 2010).

Globally and locally, it has been noted that SACCOs' performance has been increasing tremendously both economically and socially from the time they begin operations because their main aim is to develop a culture of savings and loaning (Ochigo \& Muturi (2018). In Kenya, the Counties that constitute the Lake region are Bomet, Bungoma, Busia, Homa Bay, Kakamega, Kericho, Kisii, Kisumu, Migori, Nyamira, Siaya, Tranzoia and Vihiga. The counties under the lake region not only have similar ecological zones and natural resources, but also have analogous cultural histories which dates to historical migrations and trading routes (GOK, 2019).

Despite the benefits that SACCOs gives to members, most of the DT SACCOs in the Lake region have not been performing well except a few which managed to be among the top performing DT SACCO while the rest are still struggling to meet the SASRA regulations (SASRA, 2018). The trend in the financial performance of SACCOs in the lake region is partly attributed to the mode of financing the operations. Although SACCOs in the lake region heavily rely on membership deposits and savings to finance their operations, the sustainability of membership to support financing of their needs is contentious. This makes SACCOs in the lake region to seek alternative financing modes that results in debt financing (Githire \& Muturi, 2015).

This study focused on establishing the relationship between share capital, retained earnings, members' deposits, debt financing and financial performance of SACCOs in the Lake Region Counties of Kenya. The study was prompted by the increase in the number of SACCOs in the Lake Region Counties facing financial difficulties resulting to low returns to the investors and in some instances, SACCOs being de-registered by SASRA for not meeting the SASRA regulations, thus threatening the wellbeing of the lake region's economy (SASRA, 2018).

This study is structured as follows: Chapter one provides the background of the study, statement of the problem and the general research objective. Chapter two presents relevant theoretical review and the conceptual framework. Chapter three provides details on the research design, target population, empirical modeling and data analysis while Chapter four covers data analysis results, presentations and discussions. Finally, Chapter five provides a summary of findings, conclusion, recommendations and suggested areas of future studies.

\section{Literature Review}

\section{Modigliani and Miller (1963) Capital Structure Irrelevance Theory}

Modigliani and Miller (1963) demonstrated in their seminal paper that in the absence of taxes, bankruptcy costs, transaction costs and asymmetric information and the same rate of interest of borrowing by individuals and corporations, the value of a firm is independent of its financial structure. It does not matter if the firm's capital is raised by issuing or selling debt. It does not matter what the firm's dividend policy is. The model is based on a framework that starts with assumptions of perfect competition in factor and product markets and no transaction costs.

Modigliani and Miller (1963) conclude that a firm cannot increase its value by using debt as part of its permanent capital structure. This argument is based on perfect arbitrage such that investors can assume personal debt to help financing the purchase of unlevered shares, if the value of the levered shares is greater than the unlevered ones. With perfect arbitrage any discrepancies in the value of the stocks of two hypothetical firms, one with levered shares and the other with unlevered shares, will be eliminated.

Capital structure is thus irrelevant to firm value. However, including tax deductibility of interest payments into their model, Modigliani and Miller (1963) show that borrowing will only cause the value of the firm to rise by the amount of the capitalized value of the tax subsidy. Relaxing assumptions in their original work and introducing imperfect competition, bankruptcy costs, asymmetric information, and monopoly power, financial structure appears to be an influencing factor on firm value. The introduction of tax deductibility of interest payments has an implication on the choice of capital structure. Profitability increases, non-debt tax shields reduce, and liquidity increases.

This theory is suitably applied where there is: perfect and efficient market, no transaction costs, no default risks, no taxation. M-M theory does not propose a more effective capital structure between the equity and debt capital but simply states that the source of fund is inconsequential in the stated conditions (Pandey, 2010). According to Myers, (1984), when a company goes for a debt to finance its operations, it faces challenges amongst which is to strike a balance between tax benefits and bankruptcy costs hence there is a great need to strike a balance between the two which is what trade-off theory was all about. The costs of debt which include bankruptcy costs, financial distress costs among others explain why firms do not use a $100 \%$ debt to finance their operations as suggested by Modigliani and Miller. Most of the empirical studies have found out that optimal capital structure is achieved by use of a mixture of both equity and debt capital. 
Under this theory, firms with more fixed or tangible assets should use a high proportion of debt in financing their business operations as compared to those firms with more current assets or intangible assets. At the same time, firms with high growth (usually characterized by high percentage of increase in turnover or gross profit margins) should borrow or use low levels of debt to avoid losing value through financial distress (Ogebe, 2013).

\section{Pecking Order Theory}

Pecking order theory was proposed by Myers and Majiluf (1984) and it states that firms tend to follow a certain order when it comes to financial investments priorities. According to the theory firms will always starts with retained earnings that is available, followed by borrowing of finances from outsiders and finally the last resort will be issuing of equity. This kind of thinking made it difficult to define a firm's optimal investment strategy since equity emerge at the top and bottom of the' pecking order'. By utilizing internal finances, the company benefit from not incurring any floatation cost and are not required to disclose any company proprietary financial data that could include disclosure of the firm's potential investment opportunities and earnings expected to come about as a result of going for that investment opportunity.

Myers and Majiluf (1984) study noted that underrated value can be as a result of little or no information held by a potential investor as compared to management in respect to cash flow expectations of the firm's assets both current and in future. Taking into consideration information asymmetry, investors would conclude that the management would issue equity only at the time share is overpriced. Therefore, the newly floated equity could be sold at discounted price. This will be considered as transfer of wealth from current financiers to new ones. The share floatation could therefore be avoided if the firm make use of internally generated resources such as retained earnings.

Asymmetric record can direct the choice between external and internal financial investments and between going for debts or equity financing. There exists a regular pattern through which firms follow while investing on new projects. If data is asymmetric, it is recommended to go for debts against issuing of equity since debt shows the board's confidence that investing is profitable. Issuing of equity on the contrary would signal no confidence in the board of management and hence will perceive share price being over-valued. Therefore, issuing of equity could easily lead to a general fall in share price of the firm (Matemilola \& Bany-Ariffin, 2011).

SACCOs can utilize this theory to decide how investment of their operational is done using retained profits, members' deposit, capital shares and debts financing. The pecking order theory therefore is important since SACCOs can make use of retained earnings as a priority internal investment option to fund its investment opportunities while seeking for external resourcing become last resort. This will facilitate to meet the growing demand for credit by its clients and tap opportunities on new investments.

\section{The Signaling Theory}

This theory was authored by Poterba and Summers (1985) to explain information asymmetry between company's managers and their shareholders. According to the proponents, managers have a lot of information in their possession. If the managers of a company strongly believe that the company is undervalued, they will borrow more externally and later issue equity. Similarly, if the managers believe that their companies are overvalued, they will issue equity first followed by debt.

According to Ross (1977), managers' choice of capital structure will signal information to the market. As a result, increase on a firm's leverage may be a positive sign towards the future earnings of a company. Failure to repay debt could lead to bankruptcy and hence firms with high levels of debt depict a positive signal of their capability of having sufficient cash flows to service the debt (Jensen \& Meckling, 1976). Dividend announcement by a company is a signal of a prospective future as an organization suffering from distress and bankruptcy costs mostly likely cannot announce dividend pay outs.

\section{Conceptual Framework}

Young and Wilkins (2009) state that a conceptual framework is a diagram that represents the relationship between two or more variables under study. In this study mode of financing (share capital, retained earnings, members' deposits, and debt financing) is the independent variable while financial performance is the dependent variable. These are presented in figure 2.1 below. 


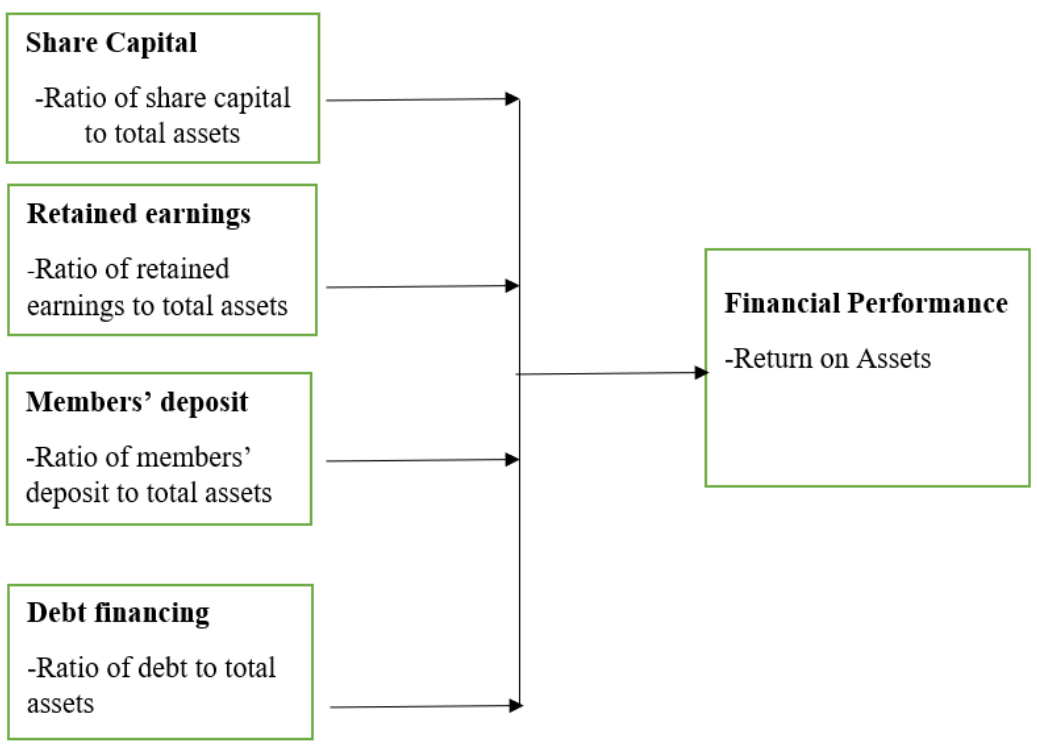

Figure 2. 1: Conceptual Framework (Authors, 2020)

\section{Research Methodology}

Ngumi (2013) states that research design is the structure or blueprint of research that guides the process of research from the time of formulating the research questions and hypothesis up to the time of reporting the research findings. This study utilized explanatory research design to determine the relationship between modes of financing and financial performance of SACCOs in the Counties of the Lake Region. Saunders et al (2003) observed that explanatory investigation looks at the existing condition of various variables at any given time-period and whether there is a link that exist between them.

The target population for this study was all the 34 licensed deposit taking SACCOs operating in the Lake Region Counties of Kenya (SASRA, 2018). According to Cooper and Schindler (2000), target population refers to all the collection of elements of a given population of study. Secondary data was collected from the audited financial statements of the 34 DT SACCOs for a period of five years between 2015 to 2019. Share capital ratio, retained earnings ratio, members' contributions ratio and debt financing ratio were derived from the audited financial statements of the authorized SACCOs on the basis of total assets.

Data was analyzed using descriptive statistics, correlation analysis and panel data regression with the help of STATA version 14. Panel data regression model was used to establish the causal relationship between financial performance and mode of financing as a resource. The panel data regression model was specified as follows:

$R_{i t}=\beta_{0}+\beta_{1} X_{1 i t}+\beta_{2} X_{2 i t}+\beta_{3} X_{3 i t}+\beta_{4} X_{4 i t}+\varepsilon_{i t}$ where $R_{i t}=$ Return on assets, $i=S A C C O$ number,

$\mathrm{t}=$ time in years, $\beta_{0}=$ intercept or constant term, $\beta_{1} \ldots \beta_{4}=$ coefficient of the independent variables, $X_{1}=$ Share Capital / Total Assets, $X_{2}=$ Retained Earnings / Total Assets, $X_{3}=$ Members' deposits / Total Assets, $X_{4}$ $=$ Debt financing/ Total Assets, and $\varepsilon=$ error term.

Diagnostic tests were carried out to ensure that the results do not in any way violate the assumptions of regression analysis. Normality test was carried out using the Jarque Bera test which is a goodness-of-fit test to check whether sample data have the skewness and kurtosis matching a normal distribution (Bera, 1987). Testing for heteroscedasticity involved the use of Breusch-Pagan test which is designed to detect any linear form of heteroscedasticity. This was done by running a regression and then give the estat hettest command (Breusch-Pagan, 1979). Multicollinearity on the other hand is a statistical phenomenon in which there exist a perfect or exact relationship between the predictor variables.

Presence of multicollinearity inflates the variances of the parameters estimates and hence it may lead to lack of statistical significance of individual predictor variable though the overall model may be significant. The presence of multicollinearity can cause serious problems with the estimation of coefficients and the interpretation. Value Inflation factor was used while testing for multicollinearity where if the VIF value is greater than 5 then there is multicollinearity otherwise if VIF value is less than 5 then it was concluded that there was no multicollinearity. According to Fisher, R, (1932), Unit root test involves testing for data stationary or nonstationary where if $\mathrm{P}$ value is equal to 1 the data is non-stationary but if $\mathrm{P}$ value is less than 1 then data is stationary. Testing for serial correlation in the data involved the use of Woodridge Drucker test (Woodridge, 2002) 


\section{Results and Discussions \\ Descriptive Statistics}

The study examined various descriptive statistics which include the mean, standard deviation, minimum and maximum values of all variables. In addition, Table 4.1 presents Skewness and Kurtosis coefficients for the variables.

Table 4. 1: Descriptive Statistics

\begin{tabular}{llllll}
\hline Variables & $\begin{array}{l}\text { Return on } \\
\text { Assets }\end{array}$ & Share Capital & $\begin{array}{l}\text { Retained } \\
\text { Earnings }\end{array}$ & $\begin{array}{l}\text { Membership } \\
\text { Deposits }\end{array}$ & $\begin{array}{l}\text { Debt } \\
\text { Financing }\end{array}$ \\
\hline Mean & .169 & 0.139 & 0.015 & 0.616 & 0.601 \\
Std. Deviation & .062 & 0.178 & 0.006 & 0.125 & 0.176 \\
Min & .059 & 0.005 & 0.004 & 0.001 & 0.115 \\
Max & .4 & 1.166 & 0.035 & 1.118 & 0.941 \\
Skewness & 1.409 & 3.688 & 1.350 & -1.105 & -.277 \\
Kurtosis & 5.580 & 18.336 & 5.481 & 8.018 & 2.453 \\
\hline
\end{tabular}

Source: (Authors, 2020)

Table 4.1 indicate that the mean of return on assets for the deposit taking SACCOs in the Lake region counties was $16.9 \%$ with standard deviation of $6.2 \%$, showing a slight deviation from the mean. The mean share capital ratio was $13.9 \%$ with standard deviation of $17.8 \%$. Concerning retained earnings, the study reports a mean value of $1.5 \%$ with a standard deviation of $0.6 \%$. Findings further indicate a mean membership deposit of $61.6 \%$ with standard deviation of $12.5 \%$. This means that members' deposits account for about 61.6 percent of the total assets of DT SACCOs during the period under study.

The mean of debt financing was $60.1 \%$ with standard deviation of $17.6 \%$. In summary, the results show that members' deposits and debt financing had a substantial contribution to total assets among the deposit taking SACCOs in the Lake region between 2015 to 2019. In addition, statistics on retained earnings contributed the least in the total assets of the SACCOs. The coefficient of Skewness show that all variables except share capital have symmetric distribution. This is because they range between -2 and +2 . Nevertheless, Kurtosis results indicates that all variables except debt financing have asymmetric distribution. For symmetric distribution, the coefficient of Kurtosis has to range between -3 and +3 .

\section{Correlation Analysis}

The correlation analysis statistics are presented in Table 4.2. According to the statistics, return on asset variable is positively correlated to both share capital and retained earnings. In addition, the findings indicate that the correlation is stronger between ROA and retained earnings (0.9915) as compared to share capital. Nevertheless, ROA is negatively correlated with membership deposits and debt financing. In addition, the correlations are weaker given that the coefficients are below 0.5 .

Table 4.2: Correlation Analysis

\begin{tabular}{llllll}
\hline & Return on Assets & Share Capital & Retained Earnings & $\begin{array}{l}\text { Membership } \\
\text { Deposits }\end{array}$ & Debt Financing \\
\hline Return on Assets & 1.0000 & & & & \\
Share Capital & 0.5547 & 1.0000 & & & \\
Retained Earnings & 0.9915 & 0.5492 & 1.0000 & 1.0000 & \\
Membership & -0.2366 & -0.1390 & -0.2362 & & \\
Deposits & & -0.3098 & -0.2561 & 0.2250 & 1.0000 \\
Debt Financing & -0.2619 & & & & \\
\hline
\end{tabular}

Source: (Authors, 2020)

\section{Econometric Results}

The study sought to investigate the effect of mode of financing on the financial performance of DT SACCOs in the Lake Region Counties. Panel data approaches were utilized in the estimation with the aid of Stata version 14. Before estimation of return-on-investment equation, the study conducted panel root test in the next sub-section.

\section{Panel root Test}

Panel root test was conducted to find out if the variables had unit roots or not. Data that is devoid of unit roots is termed as stationary, that is, data has constant means and variances over time. The presence of unit roots signifies non-stationarity in the series. Non-stationary data could lead to spurious regressions and hence, misleading results. The study adopted Harris-Tzavalis approach to check for unit roots. This model tests the null hypothesis that panel contains unit roots against the alternative hypothesis of no unit roots. This was tested at $95 \%$ confidence interval. Findings of the unit root test are contained in Table 4.3. 
Table 4.3: Panel Unit Root Test

\begin{tabular}{llccc}
\hline Variable & Order & Statistic & $\mathrm{Z}$ & P-value \\
\hline Return on Assets & Level & -0.3125 & -2.5518 & 0.0054 \\
Share Capital & Level & -0.515 & -4.6970 & 0.0000 \\
Retained earnings & Level & -0.326 & -2.6947 & 0.0035 \\
Membership Deposits & Level & -0.269 & -2.1010 & 0.0178 \\
Debt Financing & Level & -0.324 & -2.6759 & 0.0037 \\
\hline
\end{tabular}

Source: Author's computation using Stata 14

The p-values of all the variable are less than 0.05 . This signifies a rejection of null hypothesis that data was devoid of unit roots at level. Having ascertained that all variables are stationary, the study went on with the houseman test to determine the appropriate model to use.

\section{Estimation of Empirical Model}

The study considered three panel data estimation methods. These included pooled Ordinary Least Square (POLS), Fixed Effect (FE) and Random effect (RE) model. The analysis begins by estimating POLS whose results are presented in Table 4.4 .

Table 4.4: Pooled OLS Model Estimates

\begin{tabular}{|c|c|c|c|c|c|c|c|}
\hline \multicolumn{2}{|l|}{ Inroa } & Coef. & Std. Err. t & $\mathrm{P}>\mathrm{t}$ & {$[95 \% \mathrm{Co}$} & \multicolumn{2}{|c|}{ Interval] } \\
\hline Insharecap & & .006129 & .0049294 & 1.24 & 0.216 & -.0036039 & .0158619 \\
\hline Inretainearn & & .8878861 & .0239495 & 37.07 & 0.000 & .8405991 & .9351731 \\
\hline lnmemdeposit & & -.0161219 & .0144671 & -1.11 & 0.267 & -.0446864 & .0124426 \\
\hline lnDebtfinc & & -.0588071 & .024093 & -2.44 & 0.016 & -.1063774 & -.0112369 \\
\hline _cons & & 1.928162 & .1084057 & 17.79 & 0.000 & 1.714121 & 2.142203 \\
\hline$\overline{\text { Number of obs }}$ & $=$ & 170 & & & & & \\
\hline$F(4,165)$ & $=$ & 406.85 & & & & & \\
\hline Prob $>$ F & $=$ & 0.0000 & & & & & \\
\hline R-squared & $=$ & 0.9079 & & & & & \\
\hline Adj R-squared & $=0.9057$ & & & & & & \\
\hline
\end{tabular}

Source: (Authors, 2020)

According to the OLS estimates, share capital and retained earnings are positively related to return on assets while membership deposits and debt financing have a negative effect on return on assets. But, only retained earnings and debt financing variables are statistically significant. Nevertheless, POLS suffers from various shortcomings with key among them being failure to overcome selection bias. In addition, POLS do not take into account the issue of unobserved characteristics. Furthermore, Woodridge (2006) argues that FE and RE estimator accounts for individual heterogeneity which is imperative for this study. To overcome this, the study estimated both Fixed and Random Effects models. These are presented in Tables 4.5 and 4.6.

\section{Table 4.5: Fixed Effect Model Estimates}

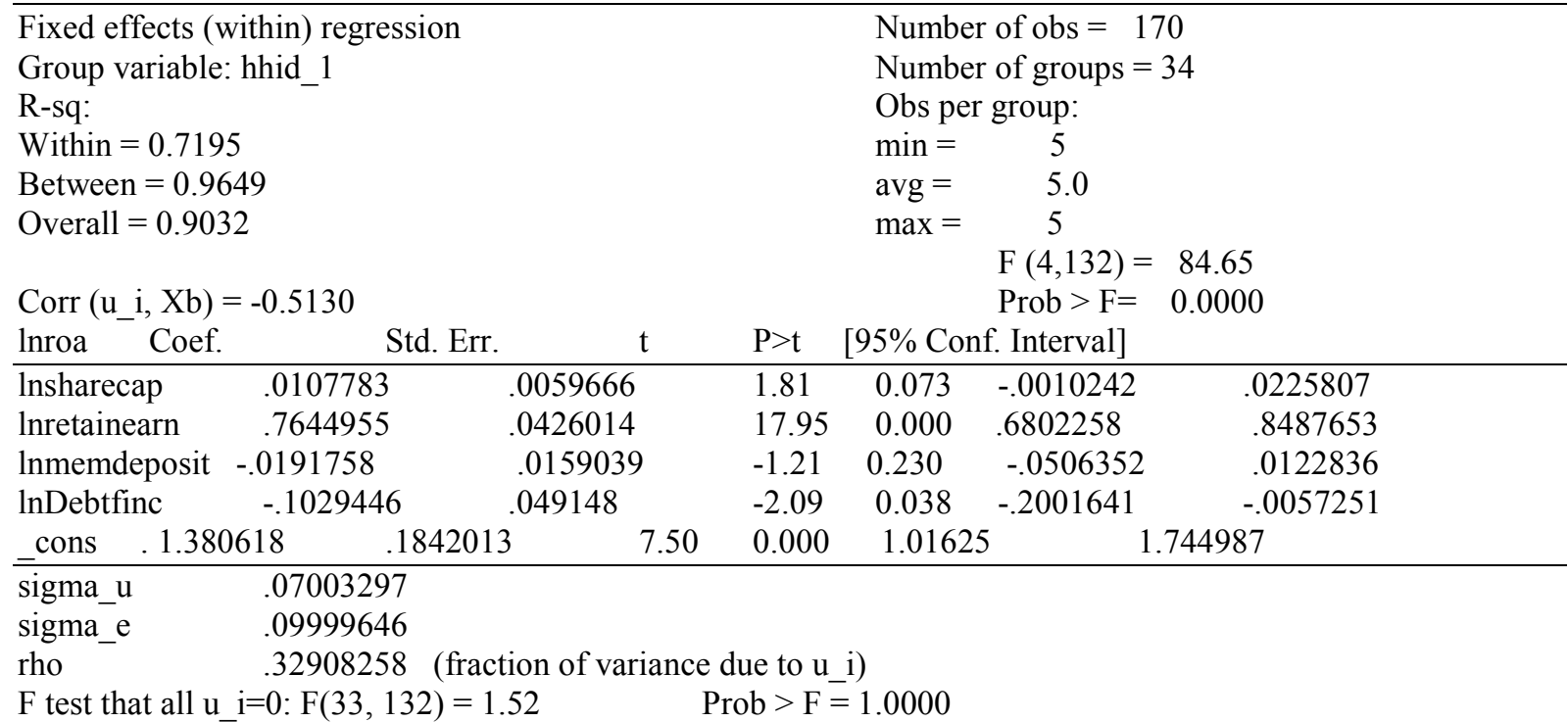

\section{Source: (Authors, 2020)}

The FE estimates show that share capital and retained earnings variables are significant, and positively related to return on assets. On the other hand, membership deposits and debt financing have a negative effect on return on 
assets. Nevertheless, the variable for membership deposits is not significant given a p-value of 0.230 which is greater than all levels of significant.

Table 4.6: Random Effects Model Estimates

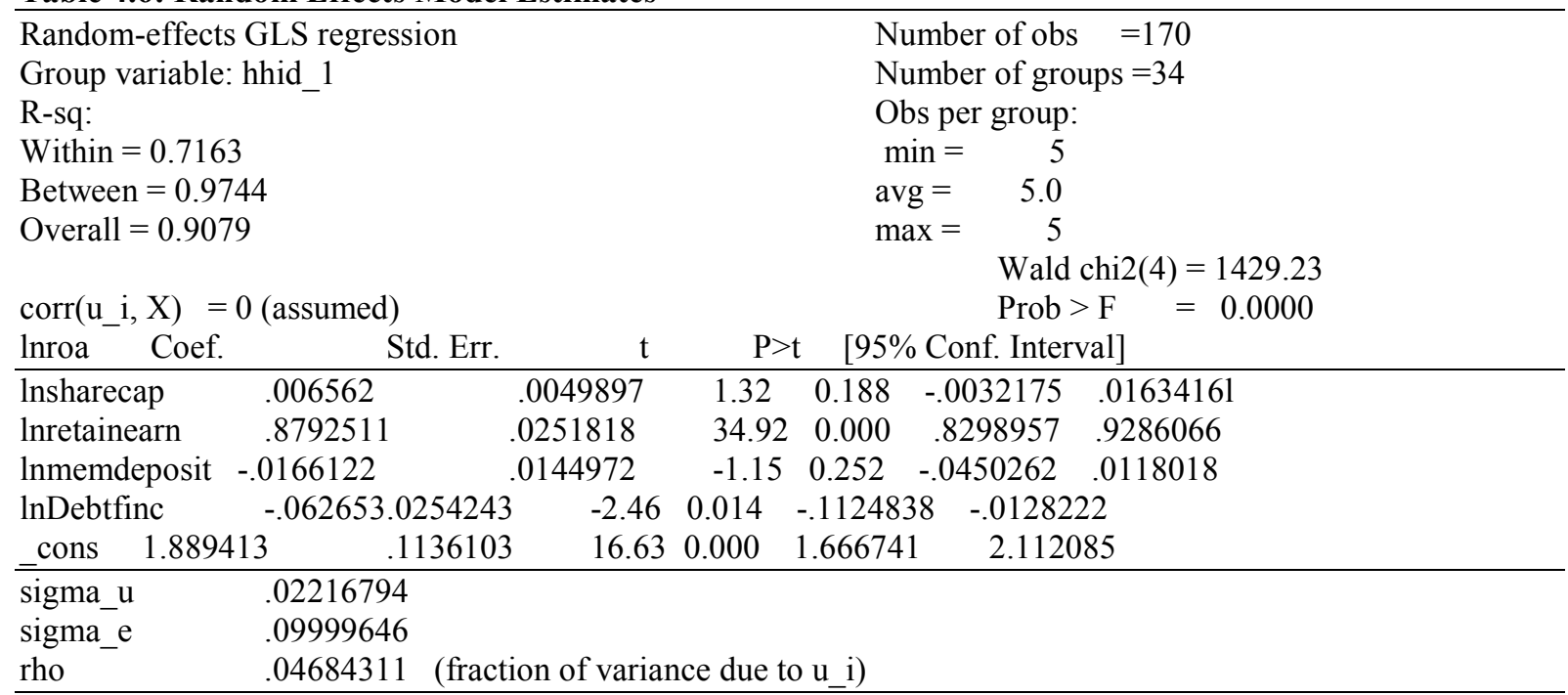

Source: (Authors, 2020)

Random effects model estimates indicate share capital and retain earnings variables are positively related to return on assets. However, the variable for share capital is not statistically significant given a p-value of 0.188 . On the other hand, membership deposits and debt financing have a negative effect on return on assets. Nevertheless, the variable for membership deposits is not significant given a p-value of 0.252 . However, according to Green, (2008) explains that the choice between FE and RE depends on the prediction of Hausman test. Thus, the results of FE and RE regressions were subjected to Hausman test with the hypothesis that FE model was the best for the study. The results of the Hausman test are presented:

Test: Ho: difference in coefficients not systematic

$$
\begin{aligned}
& \operatorname{chi} 2(4)=(b-B)^{\prime}\left[\left(V_{-} b-V_{-} B\right)^{\wedge}(-1)\right](b-B) \\
& =13.50 \\
& \text { Prob }>\text { chi } 2=0.0091
\end{aligned}
$$

The p-value of 0.0091 less than 0.05 indicates that FE was the suitable for the study. Indeed, Green (2008) argued that FE model is ideal for investigating time variant factors as is the case for the current study. Kurtosis and skewness statistics (Table 4.1) indicated the presence of outliers in the data for some variables. To overcome this challenge, the study normalizes the variables by taking natural logarithms for all variables. Table 4.7 presents estimated results based on Fixed Effect model.

\section{Table 4.4: Mode of Financing and Financial Performance of DT SACCOS (FE Model)}

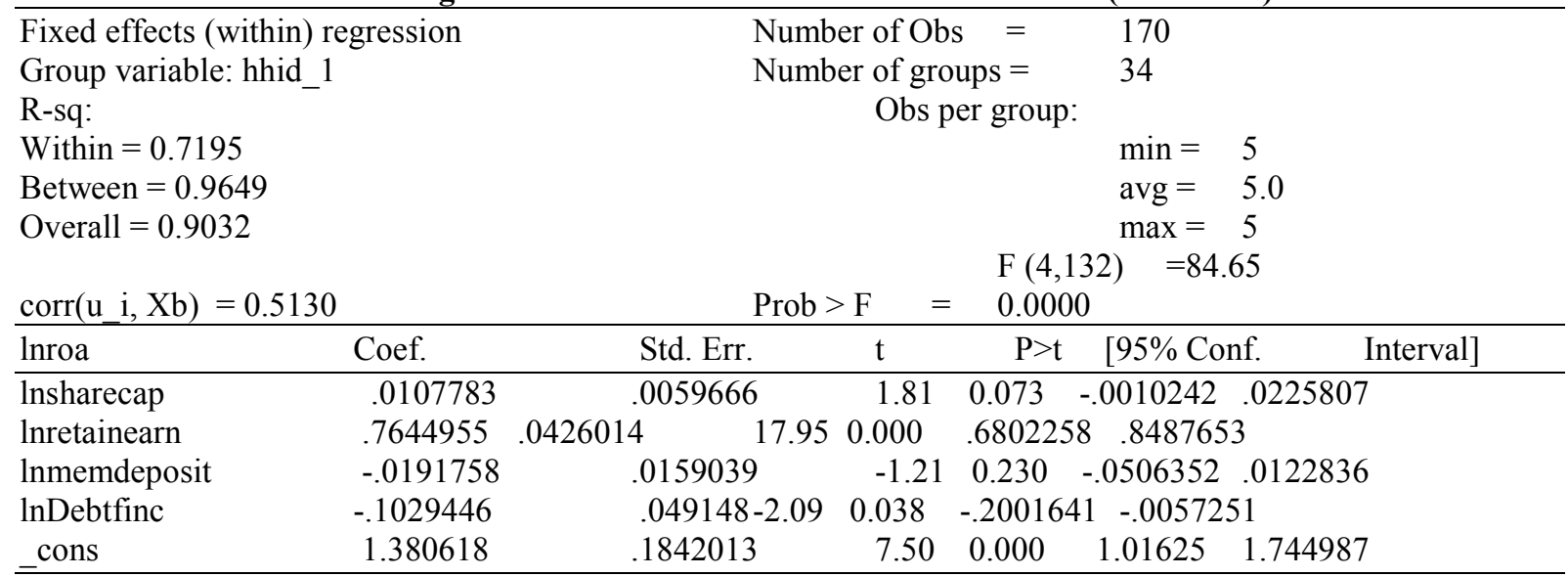

sigma u .07003297

sigma_e .09999646

rho.$\overline{3} 2908258$ (fraction of variance due to $\mathrm{u}$ i)

Source: (Authors, 2020)

The results were fitted in the regression equation: $R=\beta 0+\beta 1 X 1+\beta 2 X 2+\beta 3 X 3+\beta 4 X 4$, where, $R=$ return on total assets $X_{1}=$ share capital, $X_{2}=$ retained earnings, $X_{3}=$ members deposits, $X_{4}=$ debt financing, $\beta_{0}=$ 
is the constant ( $\mathrm{Y}$-intercept), and $\beta_{1}-\beta_{4}=$ coefficient of estimation. The fitted regression equation was: $\mathrm{R}=1.380618+0.0107783 X_{1}+0.7644955 X_{2}-0.0191758 X_{3}-0.1029446 X_{4}$

\section{Discussion of the regression Findings}

The hypothesis for the FE regression analysis was that the coefficients of explanatory variables was different from zero (0). Given the F statistic of 84.65 with the Prob $>F=0.0000$, the study accepts the hypothesis meaning that, there is significant relationship between mode of financing and return on assets of deposit taking SACCOS in the Lake region. In short, the findings indicate that the model was well fitted and hence, the results can be interpreted.

Turning to the estimated coefficients, the study reports existence of a positive relationship between return on assets and share capital. This is indicated by a positive coefficient of .0107783 . In addition, this coefficient is insignificant at $5 \%$ level ( $\mathrm{p}$-value $=0.073$ ). Hence, share capital has little contribution to returns on assets among DT SACCOS in the Lake region. Retained earnings has a significant positive relationship with returns on total assets $(0.7644955, \mathrm{P}$-value $=0.000)$. This means that retained earnings has a statistically significant contribution to the SACCOs return on assets. This argument is further reinforced by the size of the coefficient which shows that a unit increase in retained earnings will lead to $76.4 \%$ increase in return to assets among DT SACCOs in the Lake region Counties. Thus, the study finds that retained earnings have a positive effect on the financial performance.

Thuranira (2014) established that although, retained earnings had a positive effect on financial performance, the relationship was insignificant. This can be explained by differences in methodologies and target populations used to estimate results by the two studies. Thuranira results could have been compromised given that his study employed OLS which could not control for both selection bias and individual heterogeneity among firms. In addition, Thuranira's investigation focused on the firms listed at the NSE and not SACCOs and hence, there is likelihood of obtaining different results.

With regard to debt financing, the study has established existence of a significant negative relationship on return on assets $(-.1029446$, $\mathrm{p}$-value $=0.0038)$. The results imply that debt financing for the SACCOs in the Lake region counties between 2015 and 2019, had an adverse effect on the financial performance of the SACCOs. The results further indicate that a unit change in debt financing leads to about $10.3 \%$ reduction in the financial performance proxied by return on total assets. These results could imply that these SACCOs borrow relatively more expensive loans. Aziz and Abbas, (2019) for the case of Pakistan established similar results where they argued that debt financing has a negative effect on financial performance. Nevertheless, their study focused on non-financial sector.

Mutua and Atheru (2020), Namusonge, (2016) reports similar results of negatively and significantly related to financial performance. However, the result contradicted findings from Githire \& Muturi, (2015) where they found out that debt financing had a positive and significant effect on financial performance. Finally, the study could not establish a significant relationship between return on assets and members deposits. This is demonstrated by a p-value of 0.230 which is greater than 5\%. This implies that between 2015 to 2019 , members' deposits among DT SACCOs in the lake region did not have a significant effect on the financial performance.

\section{Summary of findings, Conclusion and Recommendations Summary of Findings}

Share capital and financial performance have an insignificant positive relationship implying that the share capital of SACCOs in the Lake region counties is not sufficient to influence the performance positively. Retained earnings have a significant positive effect on the financial performance of SACCOs in the Lake region counties. Retained earnings are internal sources of financing which does not cost the firm anything as opposed to loans. Retained earnings enhances the financial position of SACCOs in the lake region and makes it more favorable to the investors. This is attributed to the fact that retained earnings have no extra cost to the business in comparison to borrowing.

The study did not establish existence of a significant relationship between members' deposits and financial performance of DT SACCOs in the Lake region counties. This could be attributed to lack of substantial growth in members' deposits. However, debt financing has a significant negative relationship with financial performance of DT SACCOs in the Lake region counties implying that debt financing affects performance of DT SACCOs in the Lake region counties adversely. Borrowing comes with a cost which could explain the reason why debt financing is detrimental to the financial performance of SACCOs. These could also mean that these SACCOs take expensive loans thereby reducing revenues of the SACCOs in the lake region.

\section{Conclusion and Recommendations}

The study concludes that share capital and members' deposits have and an insignificant effect on financial performance of DT SACCOs in the Lake region counties while the effect of retained earnings and debt financing on financial performance of DT SACCOs in the Lake region counties is statistically significant. Based on these findings, the following recommendations are made: The study recommends that SACCOs should exploit internal 
sources of financing and minimize expensive debt financing for optimum financial performance. In particular, loans with favourable terms like longer repayment period and lower interest rates should be sought.

There is need to conduct a study on the nature of debt financing for the DT SACCOs in Kenya. This would help to understand which loans have an adverse effect on the financial performance. In addition, an investigation should be carried out to establish why SACCO membership deposits have no significant effect on financial performance of DT SACCOs.

\section{REFERENCE}

Abdul, G .K. (2012). The Relationship of Capital Structure Decisions with Firm Performance: A Study of the Engineering Sector of Pakistan. International Journal of Accounting and Financial Reporting, 2(1), 21623082

Abraham, R., \& Harrington, C. (2011). Seasoned equity offerings: Characteristics of firms. International Journal of Business, Humanities and Technology, 1 (3), 26- 33.

Ademba (2013). Speech for the Chief Executive Officer, SASRA during the Sacco Leaders Forum, AtKICC on 26th August, 2013.

Aftab et al., (2012), "The Effect of Corporate Strategy and Capital Structure on Performance of Banking Sector of Pakistan ".Global Journal of Management and Business Research, Vol. 12, No. 17, Pp. 21 - 32

Ahmad, N., \& Aris, Y. B. W. (2015). Does age of the firm determine capital structure decision? Evidence from Malaysian trading and service sector. International Business Management, 9(3), 200-207. https://doi.org/10.3923/ibm.2015.200.207

Andrews, D., E. Bartelsman and C. Criscuolo (2015), "Firm Dynamics and Productivity Growth in Europe" Mimeo.

Altman, E, (2002). Bankrupcy, Creditor Risk, and High yield Junk Bonds (Blackwell, Oxford).

Antoniou, A., Guney, Y., \& Paudyal, K. (2002). The determinants of corporate capital structure: Evidence from European countries. Working Paper. University of Durham, Durham

Arulvel, \& Ajanthan. (2013). Capital Structure and Financila Performance: A study of listed trading companies in Sri Lanka. Academicia: An international Multidisciplinary Research Journal, 3(6), 2249-7137.

Asquith, P. and Mullins, D.W. (1986) Equity issues and offering dilution, Journal of Financial Economics, 15, 6189.

Aziz, S., \& Abbas, U. (2019). Effect of debt financing on firm performance: A Study on nonfinancial sector of Pakistan. Open Journal of Economics and Commerce , 2 (1), 8-15.

Barber, M.B \& Lyon, J.D. (1996). Detecting abnormal operating performance: The empirical power and specification of test statistics. Journal of Financial Economics, 41, 359-399.

Barton, S.L., C.H. Ned and S. Sundaram. (1989). "An empirical test of stakeholder theory predictions of capital". Financial Management, 18(1): 36-44.

Baxter. (1967). Leverage, Risk of Ruin and the Cost of Capital. The Journal of Finance, 22(3), 395-403

Berger AN, Di Patti (2002). Capital structure and firm performance: a new approach to testing agency theory and an application to the banking industry. Feds Paper. (January 2003, paper No. 2002-54)

Bevan, A.A. and Danbolt, J. (2002) Capital structure and its determinants in the United Kingdom - A decompositional analysis, Applied Financial Economics, Vol. 12, No. 3, pp. 159-170.

Bhat, H. S., \& Zaelit, D. (2014). Forecasting Retained Earnings of Privately Held Companies With PCA and L1 Regression. Applied Stochastic Models in Business and Industry, 30(3), 271-293. https://doi.org/10.1002/asmb.1972

Breusch, T. \& Pagan, A. (1979), 'A simple test of heteroskedastici and random coefficient variation', Econometrica 47, 1287-1294.

Caroline. G., \& Willy. M. (2015). Effect of Capital Structure on Financial Performance on Firms in Kenya. Evidence from firms listed at NSE. International Journal of Economics, Commerce and Management. 3(2), 56-63.

Cheruyot R. (2015). Effect of capital structure on financial performance of listed commercial banks in Kenya. A case study of Kenya commercial bank limited. The Strategic Journal of Business and Change Management, 2 (72), 750-781

Childs, M. (2010) A conceptual framework for mediated environments, Educational Research 52, 2, June 2010, 197-213

Choi JH, Lee WJ. (2014). Association between Big 4 Auditor Choice and Cost of Equity

Capital for Multiple-Segment Firms. Accounting and Finance 54:1, 135-163.

Cooper, D. R., \& S.Schindler, P. (2008). Business Research Methods (10th ed.). Boston: Mcgraw.Hill International Edition

Cooperative Societies Act Cap 490 (2012), Cooperative Societies Act, Revised edition 2012, National council for Law reporting, Attorney General. 
Dana, L. P. (2010). "Nunavik, Arctic Quebec: Where Cooperatives Supplement Entrepreneurship," Global Business and Economics Review.

Eckbo, B. Espen, and Ronald W. Masulis, (1992), Adverse selection and the rights offer paradox, Journal of Financial Economics 32, 293-322.

Esokomi, E., \& Mutua, M. (2018). Determinants Of Financial Performance Among Savings And Credit CoOperative Societies In Kakamega County Kenya. International Journal of Finance and Accounting, , 3(1), 119.

Fabozzi, F.J and Peterson, p.p. (2003), "Financial Management and Analysis", 2ndEdition. S.1. :john wiley and sons, Inc,

Fama, E. F., (1970). Efficient Capital Markets: A Review of Theory and Empirical Work, Journal of Finance, Vol. 25, No. 2;

Fisher, R.A. (1932), "Statistical Methods for Research Workers", Oliver \& Boyd, Edinburgh, 4th Edition

Flannery, M. J. \& Hankins K. W. (2007). A Theory of Financial Structure Adjustment Speed. Working paper, University of Florida, USA.

Frank, M. \& Goyal, V. (2007); Trade-off and Pecking order theories of debt; "SSRN Electronic Journal

Gakure, R. \& Ngumi, P. (2013). Do bank innovations influence profitability of commercial banks in Kenya? Prime Journal of Social Science (PJSS) ISSN: 2315-5053. 2(3), 237- 248

Ghazouani, T. (2013). The capital structure through the trade-off theory: Evidence from Tunisian firms. International Journal of Economics and Financial Issues, 3(3), 625-636.

Ghoshal, S. (2005), "Bad Management Theories Are Destroying Good Management Practices", Academy of Management Learning \& Education, Vol. 4 No.1, pp.75-91

Girma Jirata Duguma \& Jiqin Han, (2018). "Effect of Deposit Mobilization on the Financial Sustainability of Rural Saving and Credit Cooperatives: Evidence from Ethiopia," Sustainability, MDPI, Open Access Journal, vol. $10(10)$, pages $1-23$,

Githire, C. \& Muturi, W. (2015). Effects of Capital Structure on Financial Performance of Firms in Kenya: Evidence from Firms Listed at The Nairobi Securities Exchange. International Journal of Economics, Commerce and Management. 3(4), 1-10.

Green, W. H. (2008). Econometric analysis, (6th ed)., Upper Saddle River, N.J. : Prentice Hall, 2008.

Gujarati, D. (2012). Basic econometrics. New York: McGraw-Hill.

Heshmati, A. (2008). "The dynamics of capital structure: Evidence from Swedish micro and small firms". Research in Banking and Finance, 2: 199-241.

Hofer, C. W., \& Sandberg, W. R. (1987). Improving new venture performance: Some guidelines for success. American Journal of Small Business, 12(1), 11-25.

Ibrahim, E. (2008). The impact of capital structure choice on firm performance: Empirical evidence from Egypt. Journal of Risk Finance. 10(5) 477-487

Iorpev, L., \& Kwanum, I. M. (2012). Capital Structure and Firm Performance: Evidence from Manufacturing Companies in Nigeria. International Journal of Business and Management Tomorrow, 2(5), 1-17.

Jarka, C. (2014). European Cooperative Movement - Background and common denominators; The Royal Veterinary and Agricultural University.

Jarque, C., Bera, A., (1980). Efficient tests for normality homoscedasticity and serial independence of regression residuals. Econometric Letters 6, 255-259.

Jarque, C., Bera, A., (1987). A test for normality of observations and regression residuals. International Statistical Review 55, 163-172.

Jensen M. (1986). Agency Cost free cash flow, corporate finance, and takeovers. American Economic Review,76(2), 323-329.

Jensen, M. C. \& Meckling, W. H. (1976). The theory of the firm: managerial behaviour, agency

costs and ownership structure, Journal of Financial Economics, vol. 3(4), 305-360.

John Floegel (1990) University of Pennsylvania Law Review, Vol. 138, No. 5 pp. 1411-1449

Keri, J. (2015). A Business Newsletter for Agriculture, Lowa State University Extension and Outreach, US.

Kester, W. (1986), Capital and ownership structure: a comparison of United States and Japanese manufacturing corporations, Financial Management, 15: 5-16.

Kilinde, F. (2012). Capital Structure and Firm Value; Empirical Evidence from Nigeria. International Journal of Business and Social Science. (3) 1-30.

Kioko N. (2013), The Relationship between Firm size and Financial performance of Commercial Banks in Kenya, Unpublished MBA project, University of Nairobi

Kizito, O. (2017). Effect of Capital Structure on Financial Performance of Firms in the Commercial and Service Sector in the Nairobi Securities Exchange for the period 2012 -2016.

Kongmanila, X., \& Kimbara, T. (2007). Corporate financing and performance of SMEs: The moderating effects of ownership types and management styles. The Journal of the Malaysian Institute of Management, 42(2), 
119-133. Retrieved from http://portal.mim.org.my/resources/mmr/2007/CorpFinancing.pdf

Maina, L., \& Kandongo, O. (2013). Capital Structure and Financial Performance in Kenya Evidence from Firms Listed at the Nairobi Securities Exchange. Journal of Finance and Accounting.

Makori, J., Munene, C. \& Muturi, W. (2013). The challenges facing deposit-taking Savings and Credit Cooperative Societies' regulatory compliance in Kenya. A case of the Gusii Region, Interdisciplinary Journal of Contemporary Research in Business, Vol 4, No 12

Matemilola., \& Bany Ariffin.N (2011). Pecking Order Theory of Capital Structure: Empirical Evidence from Dynamic Panel Data. International Journal Of GSTF Business Review, 1(1), 185-190.

Mauwa, J., Namusonge, P. G., \& Onyango, P. S. (2016). Effect of capital structure on financial performance of firms listed on the Rwandan stock exchange. European Journal of Business, Economics and Accountancy, 4(4), 2056-6018.

Mesquita, J.M. C. and Lara, J.E. (2003). “Capital Structure and Profitability: The Brazilian Case”, Finance, 57 (3): $1383-420$.

Mclaney, E. (2009). Business Finance Theory and Practice (8th ed.). London: Pearson Education Ltd.

McLaughlin, R., Saffiedine, A., \& Vasudevan, .G. (1996). The operating performance of seasoned equity offers: Free cashflow and post- issue performance. Financial Management, 25 (4), 41-53.

Milcah \& Muturi (2016). Financial factors affecting the performance of deposit-taking savings and credit cooperative societies in Kenya: a case of Kiambu County. International Journal of Social Science \& Information technology

Modigliani, F, and Miller, M H,(1958). "The Cost of Capital, Corporation Finance, and the Theory of Investment" American Economic Review, VO1.XLVIII, No.3, pp.261-97, reprinted in The Theory of Business Finance (2e), Stephen H. Archer and Charles A. D’Ambrosio, eds., New York, Macmillan, 1976 (page references to reprint)

Mohammed S.F (2013). "The self-help Groups (SHGS) Linkage banking programme Concept and practice in Nigeria". Abuja CBN Bullion Vol. 29no.4 Oct/Dec. Pp.43-45

Moyer, R., McGiugan, J., \& Kretlow, W. (1999). Contemporary Financial Mnagement (5th ed.). New York: West Publishers.

Mule, R.K., \& Mukras, M.S. (2015). Financial leverage and performance of listed firms in a frontier market: Panel evidence from Kenya. European Scientific Journal, 11 (7), 534-550

Muthuva, D. (2016). Determinants of Disclosure Level by Deposit Taking savings and Credit Co-operative Societies in Kenya. Jomo Kenyatta University of Agriculture and Technology.

Mutua, L., \& Atheru, G. (2020). Capital Structure and Financial Performance of Companies listed under Manufacturing and Allied Sector at Nairobi Securities Exchange in Kenya. Journal of Finance and Accounting, 4(1), 24 - 38.

Mwaniki, G., \& Omagwa, J. (2018). Asset structure and financial performance: A case of firms quoted under commercial and service sector at the Nairobi Securities Exchange in Kenya.

Myers, S. C. (2001). Capital Structure. The Journal of Economic Perspectives, 81-102.

Myers, SC, "The Capital Structure Puzzle" Journal of Finance VO1.XXXIX, No.3 (July 1984), pp.575-92

Myers S.C. and Majluf N. (1984). Corporate financing and investment decisions when firms have information that investors do not have, Journal of Financial Economics, 13, 187-221.

Munene, E. C., \& Makori, J. (2013). The challenges facing deposit-taking savings and credit cooperative societies' regulatory compliance in Kenya. A case of the Gusii region.

Narayanan, M. P. (2008). Debt versus equity under asymmetric information. The Journal of Financial and Quantitative Analysis, 23(1):39-51.

Ndatimana, E. (2008). Performance of initial public offerings: the evidence from Nairobi Stock Exchange. Unpublished MBA project, University of Nairobi.

Ochigo K. \& Muturi, (2018). Effect of customer focus strategy on the performance of Saccos in Kenya. . International Journal of Business Strategies, , 3(1), 1-16.

Oganda, A. J., Mogwambo, V. A., \& Otieno, S. (2018). Effect of Cash Reserves on Performance of Commercial Banks in Kenya: A Comparative Study between National Bank and Equity Bank Kenya Limited. International Journal of Academic Research in Business and Social Sciences, 8(9), 685-704.

Ogebe, O. P., Ogebe, J. O. \& Alewi, K. (2013). The Impact of Capital Structure on Firms' Performance in Nigeria. Journal of Risk Finance, 6 (5): 438-445.

Okoth, (2014). Relationship between lending interest rates and the performance of stocks at the Nairobi securities exchange. Unpublished MBA thesis. Nairobi: University of Nairobi

Olando, C., Jagongo A., \& Mbewa M., (2013) The contribution of SACCO financial stewardship to growth of SACCOS in Kenya. International Journal of humanities and social sciences, 3(17), 1

Omollo, W. Muturi and J. Wanjare, (2018). Effect of debt financing option on financial performance of firms listed at the Nairobi securities Exchange. Research Journal of Finance and Accounting, 9(10), 150-164 
Otieno, A. K. (2013). Capital structure of listed firms in Kenya: the case of non financial firms. Nairobi.

Otwoma, F., (2013). The effect of interest rates on property prices in the Kenyan Real estate Market. Unpublished Msc research project, University of Nairobi

Oyedokun, G.E., Job-Olatunji, K.A., and Sanyaolu, W.A., (2018). Capital structure and financial performance. Accounting \& Taxation Review, 2(1), pp.65-82

Pandey, I. M. (2015). Financial Management. New Delhi, India: Vikas Publishing House PVT ltd.

Pandey I.M. (2011). Financial Management, Vikas Publishing House PVT Ltd., India. 776

Pandey, I. M. (2010). Financial management. $9^{\text {th }}$ Edition, New Delhi: India Vikas publishing House PVL Ltd.

Pandey, I.M. (2009), Financial Management: Capital Structure Planning and Policy, pp. 332, 333

Peayler, R (2018). What is capital structure for small business? Retrieved from http://www.thebalancemb.com / capital-structuredefination-393275.

Peterson, L. W. (2017). Introduction to Investment and Finance (1st Edition ed.). Denmark: bookboon.com.

Poterba, James and Lawrence Summers, (1985) "The Economic Effects of Dividend Taxation", in E. Altman and M. Subrahmanyam, eds., Recent Advances in Corporation Finance (Homewood, IL: Dow Jones-Irwin), 227284.

Poulsen, A. (2008). Corporate financial structure. Indianapolis: Library of Economics and Liberty.

Rajan, R. G., \& Zingales, L. (1995). What do we know about Capital Structure: Some Evidence from International Data. Journal of Finance, 1421-1446

Republic of Kenya (2008). Medium Term Plan (2013 - 2017) for The financial Services Sector. Nairobi: Government printer.

Ross, Stephen A., (1977), The Determination of financial Structure: the Incentive - Signalling Approach, Bell Journal of Economics 8, 23-40.

SASRA. (2018). Guidelines on Good Governance Deposit-Taking Sacco. Nairobi: SASRA.

SASRA. (2012). Sacco Supervision Annual Report 2011: Deposit Taking SACCOs. Nairobi: SASRA.

Saunders, M. N., Lewis, P., \& Thornhill, A. (2003). Research methods for business students (3rd ed.). Harlow, England: Prentice Hall.

Servaes, H. and Tufano, P. (2006). The Theory and Practice of Corporate Capital Structure, working paper, Deutsche Bank.

Shapira, Z. (2011), "I've Got a Theory Paper---Do You?": Conceptual, Empirical, and Theoretical Contributions to Knowledge in the Organizational Sciences. Organization Science.

Shubita, M. F., \& Alsawalhah, J. M. (2012). The relationship between capital structure and profitability. International Journal of Business and Social Science. 3(16). pp. 104-112

Siro, R. O. (2013). Effect of capital structure on financial performance of firms listed at the Nairobi securities exchange. Unpublished MBA Research project, University of Nairobi.

Small Stocks Harris, M. \& Raviv, A. (2008) Theories of Financial Structure. Journal of Finance, 46(1), 297-355.

Stokes MG (2015) "Activity-silent" working memory in prefrontal cortex: a dynamic coding framework. Trends Cogn Sci 19:394-405.

Taiwo, A.M. (2012). An Empirical Analysis of Capital Structure on Firms Performance in Nigeria. International Journal of Advances in Management and Economics, 1(5), 116-124

Thuranira, M. G. (2014). The Effect Of Retained Earnings On The Returns of Firms Listed At The Nairobi Securities Exchange (Doctoral dissertation, University Of Nairobi)

Titman, S. and R. Wessels. (1988) "The determinants of capital structure choice”. Journal of Finance, 43(1): 119.

Um, T., (2001). Determination of Capital Structure and Prediction of Bankruptcy in Korea, unpublished PhD thesis. Cornell University

Uremadu, S. O. \& Efobi, R. U. (2012). The impact of capital structure and liquidity on corporate returns in Nigeria: evidence from manufacturing firms. International Journal of Academic Research in Accounting, Finance and Management Sciences, 2(3), 1-16.

Wanjiru, N. A., \& Muturi, W., (2016). Factors Affecting Financial Performance of Savings and Credit CoOperative Societies: Case Study Kiambu County, International Journal of Management and Commerce Innovations, 3 (2), 197-205.

Woodridge, J. M.: (2002), Econometric Analysis of Cross Section and Panel Data, MIT Press, Cambridge, MA. 2 , 4

Woodridge, J.M. (2006). Introductory Econometrics (4 ${ }^{\text {th }}$ ed): A Modern Approach. Michigan: South-Western Cengage Learning

Young, A., \& Wilkins, E. (2009). Dispositional statements on student teacher evaluation instruments: Commonalities across institutions. The Teacher Educator, 43(3), 198-215. 


\section{Appendix}

Appendix III: Data Collection Sheet/ Questionnaire

Name of the Financial Institution

Date of Licensed /Registered.

Physical address

Part I: Share Capital

\begin{tabular}{|l|l|l|l|l|l|}
\hline & $\mathbf{2 0 1 5}$ & $\mathbf{2 0 1 6}$ & $\mathbf{2 0 1 7}$ & $\mathbf{2 0 1 8}$ & $\mathbf{2 0 1 9}$ \\
\hline Share Capital & & & & & \\
\hline Total Assets & & & & & \\
\hline $\begin{array}{l}\text { Share Capital/Total } \\
\text { Assets }\end{array}$ & & & & & \\
\hline
\end{tabular}

\section{Part II: Retained Earnings}

\begin{tabular}{|l|l|l|l|l|l|}
\hline & $\mathbf{2 0 1 5}$ & $\mathbf{2 0 1 6}$ & $\mathbf{2 0 1 7}$ & $\mathbf{2 0 1 8}$ & $\mathbf{2 0 1 9}$ \\
\hline Retained Earning & & & & & \\
\hline Total Assets & & & & & \\
\hline $\begin{array}{l}\text { Retained Earning/Total } \\
\text { Assets }\end{array}$ & & & & & \\
\hline
\end{tabular}

Part III: Members Deposit

\begin{tabular}{|l|l|l|l|l|l|}
\hline & $\mathbf{2 0 1 5}$ & $\mathbf{2 0 1 6}$ & $\mathbf{2 0 1 7}$ & $\mathbf{2 0 1 8}$ & $\mathbf{2 0 1 9}$ \\
\hline Members Deposit & & & & & \\
\hline Total Assets & & & & & \\
\hline $\begin{array}{l}\text { Members deposit/Total } \\
\text { Assets }\end{array}$ & & & & & \\
\hline
\end{tabular}

\section{Part IV: Debt financing}

\begin{tabular}{|l|l|l|l|l|l|}
\hline & $\mathbf{2 0 1 5}$ & $\mathbf{2 0 1 6}$ & $\mathbf{2 0 1 7}$ & $\mathbf{2 0 1 8}$ & $\mathbf{2 0 1 9}$ \\
\hline Debt finance & & & & & \\
\hline Total Assets & & & & & \\
\hline $\begin{array}{l}\text { Debt finance/Total } \\
\text { Assets }\end{array}$ & & & & & \\
\hline
\end{tabular}

